\section{WATER SUPPLIES}

(1) Studies in Water Supply. By Dr. A. C. Houston. Pp. xii +203 . Macmillan's Science Monographs. (London: Macmillan and Co., Ltd., I9r3.) Price 5s, net.

(2) Water: its Purification and Use in the Industries. By W. W. Christie. Pp. xi+2ig. (London: Constable and Co., Ltd., r9r3.) Price 8s. $6 d$. net.

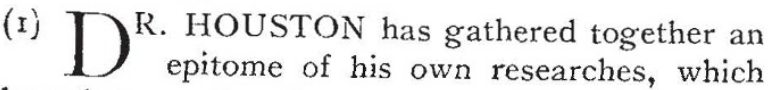
have been scattered among a considerable number of reports and papers. In the first chapter, which deals with sources of water-supply, he directs attention to the remarkably low death-rate from typhoid fever in London during the past few years, a rate which in the year I9I I amounted to only $0^{\circ} .3$ per thousand of the population. After discussing the rivers Thames and Lea as sources of water-supply, he proceeds in subsequent chapters to give results of his observations upon the purification of water, finally concluding the volume by a discussion and description of the methods carried out under his direction in the laboratories of the Metropolitan Water Board.

The main conclusions which Dr. Houston draws from a large amount of experimental work may be summarised as follows:--River water exposed to manifold pollutions, and furnishing ample chemical and bacteriological evidence of objectionable contamination, may fail to show any or scarcely any of the microbes of water-borne disease; and he raises the question as to whether we have not exaggerated the value, high as it is, of the sand filter as a factor in our long-continued immunity from typhoid fever, and whether some at least of this freedom may not be due to the fact that the water was not primarily so noxious as it has hitherto been regarded. He is convinced that artificially-added typhoid bacilli die fairly rapidly in stored water, even when such water is of great initial impurity, and that a preliminary storage of water is an important factor of safety. This purification of water under storage conditions is chiefly due to the sedimentation, equalisation, and devitalisation of microbes; and he shows that by the second week the reduction in the artificially cultivated typhoid bacilli added to river water is more than 99 per cent. on the average, and that storage reduces the number of bacteria of all sorts and devitalises the survivors, if sufficiently prolonged.

Taking the chemical and bacteriological results together, Dr. Houston demonstrates that the beneficial effect observed in connection with simple continuous flow settlement of water may be considerably enhanced by the use of coagulants, such

No. 23I9, VOL. 93] as aluminoferric, etc. He finds that when a hard water is overdosed with lime a considerable bactericidal effect is produced; and if after a suitable interval sufficient untreated water is added to combine with the excess of lime, a much safer water for drinking purposes is obtained. Speaking generally, these experiments demonstrate that the bactericidal dose of lime for hard waters would appear to be rather less than I to 5000 , and with very soft waters $\mathrm{I}$ to 50,000 . This method is especially attractive in cases where a water, bacteriologically impure, has in any event to be softened, and where a contaminated river supply has scarcely any available storage accommodation prior to sand filtration.

The author is to be congratulated, not only upon the good work to which the volume bears testimony, but also upon bringing it together in this monograph, and presenting it in a condensed and readable form.

(2) Mr. Christie's small work is mainly composed of a series of articles which appeared in "lndustrial Engineering and Engineering Digest" for I9ro-Igr $x$, and it is to be commended more particularly for its treatment of the use of water in various branches of industry. While much useful information is given upon the subject of the purification of water which would fit it for drinking purposes, this portion of the book is less satisfactorily dealt with than that which is concerned with the use of water for industrial purposes. Indeed, the treatment of the sources of water, its analysis and standards of purity, is fragmentary and unsatisfactory. It is impossible to deal with the subject of the standards of purity of water except in regard to the sources from which the water is derived. More particularly is this necessary with reference to chlorine standards; and the standard given for chlorine in water, of from 3 to Io parts in a million, is useless and misleading. Extremely few of the drinking water supplies of this country would conform to such a standard. The chapters on water softening, pressure filters, oil filters, and boiler waters are the best contributions to a work which is exceedingly well produced, the illustrations being a noteworthy feature of the publication.

\section{OUR BOOKSHELF.}

From the Letter-Files of $S$. W. Johnson. Edited by his Daughter, Elizabeth A. Osborne. Pp. 292. (New Haven: Yale University Press; London: Oxford University Press, 19I3.) Price ros. $6 d$. net.

No teacher of agricultural chemistry can afford to do without Johnson's two books, "How Crops Grow," and "How Crops Feed." If he tries it, 